\title{
ANALISIS ASPEK HUKUM STUDI KELAYAKAN BISNIS
}

\author{
Indah Ramadhona
}

Program Studi Perbankan Syariah, Fakultas Ekonomi dan Bisnis Islam, Universitas Islam Negeri Alauddin Makassar, Sulawesi Selatan, Indonesia

Email: indahramadhona1512@gmail.com

\begin{abstract}
Abstrak
Analisis aspek hukum merupakan aspek yang pertama kali harus dikaji. Hal ini karena jika berdasarkan analisis analisis pada aspek hukum sebuah ide bisnis sudah tidak layak maka proses tersebut tidak perlu diteruskan dengan analisis pada aspek-aspek yang lain. Tujuan aspek hukum yaitu:1). Menganalisis legalitas usaha yang dijalankan, 2). Menganalisis ketepatan bentuk badan hukum dengan ide bisnis yang akan dilaksanakan, 3). Menganalisis kemampuan bisnis yang akan diusulkan dalam memenuhi persyaratan perizinan.. 4). Menganalisis jaminan-jaminan yang bisa disediakan jika bisnis akan dibiayai dengan pinjaman. Bentuk bentuk badan hukum meliputi: a). perusahaan perseorangan, b). Firma, $c$ ). perseroan komanditer, d). perseroan terbatas, e). perusahaan negara, $f$ ). Koperasi, dan $g$ ). yayasan
\end{abstract}

Kata kunci : Aspek Hukum, Bentuk badan hukum 


\section{BAB I}

\section{PENDAHULUAN}

Usaha atau bisnis yang telah berjalan pada akhirnya di kemudian hari menimbulkan masalah. Masalah masalah yang timbul kadang-kadang sangat vital, sehingga usaha yang semula dinyatakan layak untuk semua aspek, ternyata menjadi sebaliknya. Hal ini disebabkan karena kurang teliti dalam penilaian di bidang hukum sebelum usaha tersebut dijalankan.

Tujuan dari aspek hukum adalah menganalisis legalitas usaha yang dijalankan, menganalisis ketepatan bentuk badan hukum dengan ide bisnis yang akandilaksanakan, menganalisis kemampuan bisnis yang akan diusulkan dalam memenuhi persyaratan perizinan.

Aspek hukum mengkaji ketentuan hukum yang harus dipenuhi sebelum menjalankan usaha. Ketentuan hukum untuk jenis usaha berbeda-beda, tergantung pada kompleksitas bisnis tersebut. Adanya otonomi daerah menyebabkan ketentuan hukum dan perizinan antara daerah yang satu dengan daerah yang lain berbeda-beda. Oleh karena itu, pemahaman mengenai ketentuan hukum dan perizinan investasi untuk setiap daerah merupakan hal yang sangat penting untuk melakukan analisis kelayakan aspek hukum. 


\section{BAB II}

\section{PEMBAHASAN}

\section{A. PENGERTIAN ASPEK HUKUM}

Aspek hukum mengkaji ketentuan hukum yang harus dipenuhi sebelum menjalankan usaha. Ketentuan hukum untuk jenis usaha berbeda beda, tergantung pada kompleksitas bisnis tersebut. Adanya otonomi daerah menyebabkan ketentuan hukum dan perizinan antara daerah yang satu ddengan daerah yang lain berbeda beda,. Oleh karena itu, pemahaman mengenai ketentuan kebohongan dan perizinan investasi untuk setiap daerah merupakan hal yang sangat penting untuk melakukan analisis kesesuaian aspek hukum.

Adapun tujuan dari analisis aspek hukum dalam studi kelayakan bisnis yaitu untuk meneliti keabsahan, kesempurnaan, dan keaslian dokumen-dokumen yang dimiliki. Penelitian keabsahan dokumen dapat dilakukan sesuai dengan lembaga yang mengeluarkan dan mengesahkan dokumen yang bersangkutan.

Berikut ini disajikan jenis data, sumber data dan cara memperoleh data dan cara menganalisis data yang terkait dengan aspek hukum

1. Jenis data dan sumber data Jenis data yang disajikan secara umum yaitu data kuantitatif yang mencakup tentang bentuk badan usaha, izin usaha dan izin lokasi pendiriaan proyek atau bisnis. Semua ini dapat diperoleh dari sumber ekstern seperti notaris, pemda, departemen terkait maupun pemeritah setempat.

2. Cara memperoleh dan menganalisis data

Untuk memperoleh gambaran kelengkapan data dasar dan data yang harus dipenuhi tentang izin usaha dan izin lokasi pendirian dapat digali dengan teknik wawancara dan dokumentasi.

(PongaBlogger, 2017) 
B. JENIS-JENIS BADAN HUKUM USAHA

1. Perseorangan

Merupakann badan usaha yang kepemilikan dan pengelolaannya ditangani

oleh satu orang. Dalam sisi pengelolaannya, pengusaha memperoleh

semua keuntungan perusahaan namun juga menanggung semua resiko

yang timbul dalam kegiatan perusahaan.

Langkah mendirikan badan usaha perseorangan:

Persiapan :

- Menyiapkan KTP dari pihak yang bersangkutan

- Menentukan calon nama perusahaan

- Menentukan tempat kedudukan perusahaan

- Menentukkan tujuan spesifik perusahaan

Pendaftaran ke Notaris:

- Untuk mendapatkan akta notaris tentang pendirian usaha

\section{Kelebihan perusahaan perseorangan:}

1) Mudah dibentuk dan dibubarkan

2) Penguasaan sepenuhnya terhadap keuntungan yang diperoleh

3) Kebanggaaan dan penguasaan dapat memimpin perusahaan sendiri

4) Pengelolaan perusahaan sederhana

5) Tidak dikenakan pajak berganda

\section{Kelemahan perusahaan perseorangan:}

1) Tanggung jawab tidak terbatas atas resiko kerugian

2) Keterbatasan sumber daya modal

3) Kemampuan manajemen terbatas

4) Keuntungan yang kecil

5) Pertumbuhan terbatas

6) Komunitas kapasitas kerja terbatas 


\section{Persekutuan}

Adalah perusahaan yang memiliki dua pemodal atau lebih. Pembentukan persekutuan bisa berdasarkan kontrak tertulis atau kesepakatan yang legal. Persekutuan terdiri dari Firma dan persekutuan komanditer/CV

\section{a) Firma}

Adalah tiap-tiap persekutuan perdata yang didirikan untuk menjalankan perusahaan dengan nama bersama.

Firma didirikan dengan sebuah akta ntaris dan didaftarkan di kepaniteraan pengadilan negeri,tidakdiperlukan adanya pengesahan departeme kehakiman

b) Persekutuan Komanditer/CV

Adalah suatu persekutuan untuk menjalankan suatu perusahaan yang dibentuk antara satu orang atau beberapa orang persero yang bertanggung jawab pada satu orang atau beberapa orang persero

\section{Kelebihan persekutuan:}

1) Mudah dalam pembentukannya

2) Penyatuan pengetahuan dan keterampilaan

3) Sumber daya modal lebih besar

4) Kemampuan menarik dan mempertahankan karyawan

5) Keuntungan dari sisi pajak

\section{Kelemahan Persekutuan:}

1) Tanggungjawab tidak terbatas

2) Tenggang waktu operasi yang terbatas

3) Perselisihan diantara partner

4) Ada halangan untuk membubarkan karena ada komitmen untuk berpartner 


\section{Perseroan Terbatas (PT)}

Pengertian perseroan Terbatas menurut Undang-Undang:

“ Badan hukum yang didirikan berdasarkan perjanjian yang melakukan kegiatan usaha dengan modal tertentu yang seluruhnya terbagi dalam saham dan memenuhi persyaratan yang ditetapkan undang-undang ini serta peraturan pelaksanaannya"

Langkah mendirikan badan usaha perseroan terbatas:

- Pembuatan akta notaris

- Anggaran dasar

- Pengesahan menteri kehakiman

- Pendaftaran wajib

- Pengumuman dalam tambahan berita Negara (TBN)

\section{Kelebihan PT:}

1) Kelangsungan hidup perusahaan terjamin

2) Terbatasnya tanggungjawab, sehingga tidak menimbulkan resiko bai kekayaan pribadi maupun kekayaan keluarga pemilik

3) Saham dapat diperjualbelikan dengan relative mudah

4) Kebutuhan modal lebih besar akan mudahh dipenuhi

5) Pengelolaan perusahaan dapat dilakukan lebih efisien

\section{Kelemahan PT:}

1) Biaya pendiriannya relative mahal

2) Rahasianya tidak terjamin

3) Kurangnya hubungan yang efektif antara pemegang saham

4) Permasalahan administrasi yang rumit

5) Pengenaan pajak berganda 
6) Adanya inefiensikerja, tidak fleksibel dan tidak kompetitif karena ukuran yang besar (Sagoro, 2020)

\section{Perusahaan Negara}

Adalah badan usaha yang sebagian atau seluruh kepemilikannya dimiliki noleh Negara Republik Indonesia.perusahaan Negara dipimpin oleh seorang kepala atau direksi yang diangkat oleh pemerintah. Perusahaan Negara dibagi dalam beberapa jenis: perusahaan jawatan ( Perjan), perusahaan umum (Perum), dan perusahaan perseorangan (persero)

\section{Perusahaan Daerah}

Merupakan perusahaan yang didirikan dengan suatu peraturan daerah. Modal seluruhnya atau sebagian besar milik pemerintah daerah yang dipisahkan kecuali dengan ketentuan lain dengan atau berdasarkan undang-undang.

Tujuan didirikannya perusahaan daerah adalah untuk turut serta melaksanakan pembangunan daerah khususnya dan pembangunan ekonomi nasional.

\section{Yayasan}

Adalah organisasi yang berbentuk korporasi untuk memberikan pelayanan kepada masyarakat.

Yayasan didirikan dengan tujuan social, bukan untuk mencari keuntungan. Kekayaan yayasan terpisah dari kekayaan anggotanya. Dana operasional diperoleh dari sumbangan para donator.

Langkah mendirikan yayasan:

- Penyampaian dokumen

- Penandatanganan akta pendiriran yayasan

- Pengurusan surat keterangan domisili 
- Pengurusan NPWP

- Pengesahan menjadi badan hukum di Dep. Kehakiman \& HAM

- Pengumuman dalam berita Negara republic (BNRI)

\section{Koperasi}

Adalah jenis badan usaha yang beranggotakan orang orang atau badan hukum.

Pendirian koperasi nelalui akta pendirian setelah memperoleh pengesahan pemerintah dan diumumkan dalam berita Negara. Untuk mendirikan koperasi dibentuk melalui rapat anggota minimal 20 orang yang masingmasing memenuhi tiga syarat, yaitu:

1) Mampu melaksanakan tindakan hukum

2) Menerima landasan idiil, asas, dan sendi dasar koperasi

3) Sanggup dan bersedia melakukan kewajiban dan hak sebagai anggota koperasi

\section{JENIS JENIS IZIN USAHA}

Perizinan berusaha adalah persetujuan yang diperlukan pelaku usaha untuk memulai dan menjalankan usaha dan diberikan dalam bentuk persetujuan yang dituangkan dalam bentuk surat/keputusan setelah pelaku usaha tersebut memenuhi semua persyaratan yang telah ditentukan.

Fungsi perizinan adalah untuk membina,mengarahkan, mengawasi juga menerbitkan kegiatan-kegiatan tertentu, maka kewajban untuk menjaga kualitas produk telah dimasuukkan ke dalam suatu prosedur perizinan, baik dalam proses pengajuan permohonan hingga pelaksanaan setelah para pelaku usaha memperoleh izin.

Dalam praktiknya terdapat beragam izin. Banyaknya izin dan jenisjenis izin yang dibutuhkan tergantung dari jenis usaha yang dijalankan. Adapun izin yang dimaksud adalah:

1) Tanda Daftar Perusahaan (TDP)

2) Nomor Pokok Wajib Pajak (NPWP) 
3) Izin-izin usaha

4) Sertifikat tanah atau surat berharga yang dimiliki.

Izin-izin perusahaan lainnya yang harus segera diurus bagi pemilik usaha dan yang harus dinilai oleh penilai adalah sesuai dengan jenis bidang usaha perusahaan tersebut. Izin-izin tersebut antara lain:

a. Surat Izin Usaha Industri (SIUI)

SIUI adalah surat yang sangat dibutuhkan oleh para pengusaha kecil menengah untuk mendirikan usaha industri

b. Surat Izin Tempat Usaha (SITU)

SITU merupakan izin yang harus dimiliki oleh pelaku usaha perseorangan, perusahaan, dan badan usaha sebagai bukti izin tempat usaha yang kamu dirikan telah sesuai dengan tata ruang wilayah yang diperlukan dalam rangka penanamaan modal.

c. Surat Izin Usaha Perdagangan (SIUP)

SIUP adalah surat izin yang dibuat oleh pemerintah Daerahyang diperuntukan bagi pelaku usaha yang melaksanakan kegiatan usaha perdagangan.

d. Izin Usaha Perhotelan \& Pariwisata

Adalah surat usaha yang harus dimiliki perusahaan yang bergerak di bidang jasa perhotelan $\&$ pariwisata

e. Izin Usaha Peternakan \& Pertanian

Adalah surat usaha yang harus dimiliki perusahaan yang bergerak di bidang peternakan $\&$ pertanian

f. HO (surat izin gangguan)

Hinderoordonnantie (HO) adalah surat keterangan yang menyatakan tidak adanya warga sekitar yang merasa keberatan dan terganggu atas lokasi usaha yang dijalankan oleh suatu kegiatan usaha disuatu tempat.

g. Izin Mendirikan Bangunan (IMB)

IMB merupakaan perizinan yang dikeluarkan oleh Pemerintah Daerah kepada pelaku usaha ataupun badan hukum yang akan mendirikan sebuah bangunan baru, mengubah, memperluas, mengurangi, dan/atau merawat 
bangunan gedung sesuai dengan persyaratan administrative dan persyaratan teknis yang berlaku

h. Izin Usaha Tambang Adalah izin yang diberikan untuk melakukan kegiatan usaha jasa pertambangan

i. Izin Usaha Farmasi \& Rumah Sakit Adalah izin yang diberikan untuk usaha pembuatan obat dan mendirikan rumah sakit (pengadaan.web.id, 2019)

\section{DOKUMEN YANG DITELITI}

\section{Bentuk Badan Usaha}

Ada beberapa jenis bentuk badan hukum yang lazim diindonesia, misalnya Perseroan Terbatas (PT), Perseroan Komanditer (CV), Koperasi, yayasan, dan firma. Kebanyakan perusahaan yang akan melakukan suatu investasi, biasanya merupakan perusahaan yang besar, baik dari segi modal maupun jangkauan usahanya. Oleh karena itu, biasanya perusahaan yang melakukan banyak studi kelayakan sebelum melakukan usahanya adalah perusahaan yang berbadan hukum Perseroan Terbatas (PT).

\section{Bukti Diri}

Yaitu kartu identitas para pemilik usaha yang dikeluarkan oleh kelurahan seetempat yang dikenal dengan nama kartu tanda penduduk (KTP)

\section{Tanda Daftar Perusahaan (TDP)}

Dalam hal ini, yang perlu kita teliti adalah ke departemen teknis yang mengeluarkan surat tanda daftar perusahaan tersebut. Departemen teknis yang mengeluarkan TDP adalah departemen perindustrian dan perdagangan. Biasanya pengurus TDP adalah pada saat perusahaan mengurus akta pendirian perusahaan tersebut. 


\section{Nomor Pokok Wajib Pajak (NPWP)}

Merupakan hal yang penting untuk dteliti, apakah sudah dimiliki atau belum. Jika sudah diteliti dapatkah kita mengeceknya ke departemen teknis yang mengeluarkan NPWP. Pengurusan NPWP juga dilaksanakan bersamaan dengan pengajuan akta notaris ke Departemen Kehakiman. Pentingnya NPWP agar setiap usaha yang dijalankan nantinya akan memberikan penghasilan kepada pemerintah.

\section{Izin-izin perusahaan}

Penelitian keabsahan dokumen izin-izin ini juga hendaknya dijalankan ke Departemen teknis. Izin-izin antara lain:

a. Surat Izin Usaha Perdagangan (SIUP) dari Departemen Perdagangan dan Perindustrian

b. Surat Izin Usaha Industri (SIUI) dari Departemen Perdagangan dan Perindustrian

c. Izin Usaha Tambang dari Departemen Pertambangan

d. Izin Usaha Perhotelan dan Pariwisata dari Departemen Pariwisata Pos dan Telekomunikasi

e. Izin Usaha Farmasi dan Rumah Sakit dari Departemen Kesehatan

f. Izin Usaha Peternakan dan Pertanian dari Departemen Pertanian

g. Izin domisili perusahaan dari Pemda

h. (HO) Izin gangguan

i. Izin Mendirikan Bangunan(IMB)

j. Izin tenaga kerja asing jika ada

\section{Keabsahan dokumen lainnya}

a. Status hukum tanah

Keabsahannya sertifikat tanah sampai ke pihak yang berwenang mengeluarkannya seperti Badan Pertanahan Nasional (BPN). Yang perlu diperhatikan adalah status tanah tersebut antara lain:

1) Jenis hak atas tanah: 
- Hak milik

- Hak guna bangunan

- Hak guna usaha

- Hak pakai

- Hak sewa

2) Harga tanah sekarang dan prediksi dimasa yang akan datang

3) Nama dan alamat pemilik sebenarnya

4) Kondisi tanah dalam sengketa atau tidak

5) Rencana tata kta

6) Tanah tersebut dapat diperjualbbbelikan atau tidak, karena tanah yang tidak dapat diperjualbelikann yaitu:

- Tanah adat

- Tanah wakaf

- Tanah sengketa

- Tanah transmigrasi

- Tanah badan pemerintah

b. Kendaraan bermotor

Keaslian surat-surat kendaraan yang akan digunakan untuk usaha tersebut seperti usaha jasa angkutan, yaitu:

1. Bukti pemilikan kendaraan bermotor

2. Harga beli (faktur dan kuitansi)

3. Kondisi kendaraan

4. Izin trayek, jika usaha transportasi

c. Serta surat-surat atau sertifikat lainnya yang kita anggap perlu (Kasmir \& Jakfar, 2012)

\section{E. PENELITIAN LAPANGAN}

1) Menandatangani sumber informasi yang berhak mengeluarkan surat-surat atau dokumen-dokumen

2) Mencari informasi dari laporan, Koran,majalah, atau perpustakaan yang relevan dengan analisis kita (Lesmono, 2019) 


\section{BAB III}

\section{PENUTUP}

\section{A. KESIMPULAN}

Aspek hukum mengkaji tentang legalitas usulan proyek atau bisnis yang akan dibangun dan dioperasikan, ini berarti bahwa setiap proyek atau bisnis yang akan didirikan dan dibangun diwilayah tertentu haruslah memenuhi hukum dan tata peraturan yang berlaku di wilayah tersebut. Jenis bidang usaha seperti Perseorangan,Perseroan Terbatas(PT), Firma, Perseroan Komanditer (CV), Perusahaan Negara, Perusahaan Daerah, Yayasan, dan Koperasi. Dalam praktiknya terdapat beragam izin. Banyaknya izin dan jenis-jenis izin yang dibutuhkan tergantung dari jenis usaha yang dijalankan. Adapun izin yang dimaksud adalah: 1). Tanda Daftar Perusahaan (TDP), 2). Nomor Pokok Wajib Pajak (NPWP), 3). Izin-izin usaha, dan 4). Sertifikat tanah atau surat berharga yang dimiliki.

\section{B. SARAN}

Menurut pendapat saya, hal yang paling penting bagi pelaku usaha yang ingin memulai sebuah bisnis harus dimulai dengan mengkaji aspek hukum di dalam pelaksanaan studi kelayakan bisnis. Sebab, apabila kita berdasarkan analisis ke aspek hukum maka akan didapatkan apakah sebuah ide bisnis itu masih layak untuk diproses atau tidak, sehingga jika memang didapatkan bahwa ide bisnis tak layak dilanjutkan dari segi aspek hukum, maka kita tidak perlu lagimeneruskan ke analisis dari aspek yang lainnya. 


\section{DAFTAR PUSTAKA}

Kasmir, \& Jakfar. (2012). Studi Kelayakan Bisnis. Jakarta: Prenadamedia.

Lesmono, S. (2019). SlidePlayer. Retrieved from https://slideplayer.info/slide/15991559/

Pengadaan. (2019). Pengadaan.web.id. Retrieved from https://www.pengadaan.web.id/2019/10/izin-usaha.html

PongaBlogger. (2017, April 19). Makalah Aspek Hukum. Retrieved from http://myblogamdin.blogspot.com/2017/04/makalah-aspek-hukum.html

Sagoro, E. M. (2020). Bentuk Badan Usaha. 